\title{
Komposisi Nutrien dan Mineral Silase Sabut Kelapa Muda pada Berbagai Level Penambahan Dedak Padi
}

\section{Minerals And Nutrient Composition of Young Coconut Husk Silage with Different Concentrations of Rice Bran}

\author{
Emilia Martha Narek ${ }^{1)}$, Floriana Petrosa Un ${ }^{1)}$, Bernadete Barek Koten ${ }^{1 *}$, Redempta Wea ${ }^{2)}$ dan \\ Aholiab Aoetpah ${ }^{1)}$ \\ 1)Program Studi Teknologi Pakan Ternak, \\ ${ }^{2}$ Program Studi Produksi Ternak, Politeknik Pertanian Negeri Kupang, \\ Jl. Prof. Dr. Herman Yohanes - Lasiana.Kotak Pos 1152, Kupang 85011.
}

\author{
Article history \\ Received: Oct 05, 2020; \\ Accepted: Feb 03, 2021 \\ * Corresponding author: \\ E-mail: \\ bernadete_koten@yahoo.com \\ DOI: \\ 10.46549/jipvet.v11i1.154
}

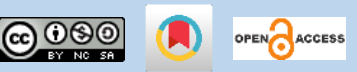

\begin{abstract}
The objective of this study was to evaluate minerals and nutrient composition of young coconut husk silage fermented with rice bran at different concentrations. The study was conducted for seven months in the Laboratory of Feed Technology of State Agricultural Polytechnic of Kupang. A completely randomised design was employed with four treatments and five replicates. The treatments were young coconut husk without rice bran (P0) or the husk plus 4\% (P1), 8\% (P2) or 12\% (P3) of rice bran out of the silage total weight. Variables measured were dry matter, ash, crude protein, crude lipid, crude fibre, Calcium, Potassium and Phosphorus. Analysis of variance showed that rice bran significantly $(\mathrm{P}<0.01)$ affects all variables measured. The Duncan's range multiple test showed that $12 \%$ and $4 \%$ were the best rice bran concentrations to increase nutrient content and minerals of the silage, respectively. It can be concluded that adding $12 \%$ of rice bran to young coconut husk silage increased dry matter, ash, crude protein and crude lipid but reduced Calcium and Potassium. Crude fibre and Phosphorus increased at the inclusion of $8 \%$ rice bran.
\end{abstract}

Key words: Nutrient; Minerals; Rice bran; Silage; Young coconut husk.

\section{Abstrak}

Penelitian yang bertujuan untuk mengevaluasi komposisi nutrien dan mineral silase sabut kelapa muda pada berbagai level penambahan dedak padi, telah dilaksanakan selama 7 bulan di Laboratorium Teknologi Pakan Politeknik Pertanian Negeri Kupang, dengan menggunakan rancangan acak lengkap dengan 4 perlakuan yang terdiri dari P0 : sabut kelapa muda tanpa dedak padi, P1 : sabut kelapa muda + $4 \%$ dedak padi, P2 : sabut kelapa muda $+8 \%$ dedak padi, P3 : sabut kelapa muda + $12 \%$ dedak padi dengan 5 kali ulangan. Variabel yang diukur adalah kadar bahan kering (BK), kadar abu, kadar protein kasar (PK), kadar lemak kasar (LK), kadar serat kasar (SK), kadar kalsium (Ca), kadar kalium, dan kadar fosfor. Analisis ragam menunjukkan bahwa level dedak padi yang berbeda berpengaruh sangat nyata $(\mathrm{P}<0,01)$ terhadap kadar BK, kadar abu, kadar PK, kadar LK, kadar SK, kadar Ca, kadar K, dan kadar P. Uji Duncan memperlihatkan level dedak $12 \%$ menghasilkan nutrien terbaik dan level 4\% menghasilkan kadar mineral terbaik. Disimpulkan bahwa penambahan level dedak padi hingga $12 \%$ dapat meningkatkan kadar BK, kadar abu, kadar PK, dan kadar LK. tetapi menurunkan kadar Ca dan kadar K. Kadar SK dan P meningkat hingga penambahan level dedak padi $8 \%$.

Kata kunci : Dedak padi; Kadar nutrient; Kadar mineral; Silase; Sabut kelapa muda. 


\section{PENDAHULUAN}

Ketersediaan pakan di Provinsi Nusa Tenggara Timur (NTT), berlimpah pada musim hujan akan tetapi sangat tidak cukup pada musim kemarau. Ternak ruminansia biasanya mengalami kekurangan pakan berkualitas yang berdampak pada rendahnya produktivitas ternak bahkan kematian. Salah satu upaya untuk menanggulangi kekurangan pakan pada musim kemarau adalah pengawetan pakan hijauan pada musim hujan dan pemanfaatan limbah, baik itu limbah pertanian maupun limbah perkebunan. Salah satu limbah yang dapat dimanfaatkan dan diolah menjadi pakan ternak adalah sabut kelapa muda.

Komposisi kimia sabut kelapa kering yaitu 5,43\% kadar air, 30,34\% serat kasar, 3,95\% kadar abu, 3,54\% lignin, 0,52\% selulosa, dan 23,70\% hemiselulosa (Adeyi, 2010). Berdasarkan nilai nutrien yang terkandungnya, maka sabut kelapa dapat diandalkan potensinya sebagai pakan ternak. Pada musim kemarau peminat kelapa muda semakin meningkat dan jumlah limbah sabut kelapa juga ikut meningkat sehingga dapat digunakan dan diolah sebagai pakan dan diharapkan dapat mengatasi kekurangan pakan hijauan pada musim kemarau. Pemanfaatan sabut kelapa muda sebagai pakan mempunyai kelemahan yaitu kualitas nutrisi yang rendah dengan kandungan serat yang tinggi. Selain itu sabut kelapa muda juga cepat sekali menjadi kering sehingga tingkat kesukaan ternak terhadap sabut kelapa muda menjadi sangat rendah. Perlu perlakuan khusus untuk meminimalisir kekurangan sabut kelapa muda tersebut. Salah satu cara pengolahan yang dapat dilakukan adalah silase.

Silase merupakan teknik pengolahan pakan melalui proses fermentasi oleh bakteri asam laktat secara anaerob, yang bertujuan untuk mengawetkan bahan pakan di dalam silo agar dapat menambah masa simpan pakan sehingga dapat digunakan pada saat kurangnya ketersediaan pakan terutama pada musim kemarau. Basri et al. (2019) menyatakan bahwa pada pembuatan silase membutuhkan bahan berkarbohidrat mudah tercerna tinggi sebagai media hidup bagi mikroba yang melakukan fermentasi seperti dedak padi. Dedak padi merupakan salah satu bahan penyusun pakan ternak yang sangat disukai, selain banyak ketersediaannya, sampai saat ini juga penggunaannya belum bersaing dengan kebutuhan pangan. Dedak padi mengandung energi metabolis sebesar $2980 \mathrm{kcal} / \mathrm{kg}$, protein kasar $12,94 \%$, lemak $6,37 \%$, serat kasar $10,58 \%$, dan abu 6,95\%. (Munira et al., 2016).

Chrysostomus et al. (2020) menyatakan penggunaan dedak padi, tapioka dan gula air sebanyak 5\% menurunkan serat kasar, dan meningkatkan kadar kalsium dan fosfor kulit pisang. Sedangkan Amrullah et al. (2015) menyatakan bahwa dengan penambahan dedak padi sebanyak $10 \%$ sebagai sumber karbohidrat dapat meningkatkan kandungan nutrien dalam silase limbah sayuran yaitu peningkatan protein kasar $0,41 \%$ dan lemak kasar 4,34\%. Sedangkan penambahan dedak padi sebanyak $5 \%$ menghasilkan silase rumput mulato dengan kandungan nutrien tertinggi dari semua perlakuan yaitu peningkatan bahan kering $5,78 \%$, protein kasar 6,06\%, lemak kasar $0,93 \%$ dan terjadi penurunan serat kasar 5,10\% (Anas and Syahrir, 2017). Terlihat bahwa penambahan dedak padi dapat mempengaruhi kandungan nutrien silase. Jumlah dedak padi menentukan tingginya aktivitas mikroba dalam proses ensilase. Aktivitas dalam proses ensilasi ini akan mempengaruhi komposisi nutrien dan kadar mineral silase sabut kelapa muda.

Penelitian ini bertujuan untuk mengevaluasi komposisi nutrien dan kandungan mineral silase sabut kelapa muda pada berbagai level penambahan dedak padi dan untuk mengetahui level dedak padi yang terbaik dalam silase sabut kelapa muda.

\section{METODE PENELITIAN}

Penelitian ini telah dilaksanakan di Kampus Politeknik Pertanian Negeri Kupang selama 7 bulan yaitu pada bulan November 2019 - Juni 2020.

Bahan yang digunakan adalah sabut kelapa muda dan dedak padi. Peralatan yang digunakan adalah parang, stoples plastik kapasitas 3,5 $\mathrm{kg}$ sebanyak 20 buah, terpal, baskom, timbangan digital merk camry kapasitas $5 \mathrm{~kg}$ skala terkecil 1 gram untuk menimbang bahan-bahan pembuatan silase, $\mathrm{pH}$ meter, mesin penggiling (disk mill) dengan ukuran saringan $1 \mathrm{~mm}$, ayakan dengan diameter $1 \mathrm{~mm}$. 
Penelitian ini menggunakan rancangan acak lengkap (RAL) 4 × $5=20$ unit percobaan, sebagai berikut : (kontrol)

P0 : sabut kelapa muda tanpa dedak padi

padi

P1 : sabut kelapa muda $+4 \%$ dedak

padi

P2 : sabut kelapa muda $+8 \%$ dedak padi

P3 : sabut kelapa muda $+12 \%$ dedak

Penelitian ini dimulai dengan pemisahan antara sabut dan tempurungnya kemudian dicacah dengan ukuran 2-4 cm, dijemur hingga kadar air mencapai 70\%. Sabut kelapa muda dicampur dengan dedak padi sesuai dengan perlakuan. Setelah itu dimasukkan ke dalam stoples plastik sambil dipadatkan, diisolasi menggunakan lakban dan disimpan selama 21 hari. Silase tersebut dibongkar dan dilakukan pemisahan silase yang baik. Sampel diambil dimasukkan ke dalam amplop koran, dan dijemur hingga kering selama \pm 3 hari, digiling halus dan diayak dengan diameter saringan 1 $\mathrm{mm}$, dimasukan dalam plastik klip dan dianalisis menurut AOAC.

Variabel yang diukur ini adalah kadar bahan kering (BK) (\%), abu (\%), protein kasar (PK) (\%), lemak kasar (LK) (\%), serat kasar (SK) (\%), kalsium (Ca) (\%), kalium(K) (\%), dan fosfor $(\mathrm{P})(\%)$. Data dianalisis varians (ANOVA) dan dilanjutkan dengan uji jarak berganda Duncan (Gomez and Gomez, 2010).

\section{HASIL DAN PEMBAHASAN}

Data pengaruh perlakuan terhadap kadar BK, Abu, PK, LK, SK,Ca, K, dan P pada silase sabut kelapa muda dapat dilihat pada Tabel 1.

Tabel 1. Pengaruh perlakuan terhadap kadar BK, Abu, PK, LK, SK,Ca, K, dan P pada silase sabut kelapa muda.

\begin{tabular}{ccccccccc}
\hline \multirow{2}{*}{ Perlakuan } & \multicolumn{4}{c}{ Komposisi nutrien } & \multicolumn{4}{c}{ Kandungan mineral } \\
\cline { 2 - 8 } & BK (\%) & Abu (\%) & PK (\%) & LK (\%) & SK (\%) & Ca (\%) & K (\%) & P (\%) \\
\hline P0 (tanpadedak- & & & & & & & & \\
kontrol) & $19,70^{\mathrm{d}}$ & $6,96^{\mathrm{d}}$ & $6,10^{\mathrm{d}}$ & $1,09^{\mathrm{d}}$ & $22,09^{\mathrm{cd}}$ & $0,39^{\mathrm{a}}$ & $2,01^{\mathrm{a}}$ & $28,58^{\mathrm{d}}$ \\
P1 (dedak 4\%) & $22,34^{\mathrm{c}}$ & $9,76^{\mathrm{c}}$ & $7,26^{\mathrm{c}}$ & $1,56^{\mathrm{c}}$ & $25,78^{\mathrm{b}}$ & $0,36^{\mathrm{b}}$ & $1,67^{\mathrm{b}}$ & $69,4^{\mathrm{b}}$ \\
P2 (dedak 8\%) & $24,98^{\mathrm{b}}$ & $10,78^{\mathrm{b}}$ & $7,82^{\mathrm{b}}$ & $2,03^{\mathrm{b}}$ & $28,53^{\mathrm{a}}$ & $0,32^{\mathrm{c}}$ & $1,45^{\mathrm{c}}$ & $73,61^{\mathrm{a}}$ \\
P3 (dedak 12\%) & $26,77^{\mathrm{a}}$ & $13,08^{\mathrm{a}}$ & $8,36^{\mathrm{a}}$ & $2,21^{\mathrm{a}}$ & $21,98^{\mathrm{d}}$ & $0,25^{\mathrm{d}}$ & $1,16^{\mathrm{d}}$ & $57,73^{\mathrm{c}}$ \\
\hline
\end{tabular}

Keterangan : Superskrip ${ }^{\text {a,b,c,d }}$ yang berbeda pada kolom yang sama menunjukkan perbedaan yang nyata $(\mathrm{P}<0,05)$.

Pengaruh Perlakuan Terhadap Komposisi Nutrien Silase Sabut Kelapa Muda

Analisis ragam menunjukkan bahwa penambahan level dedak padi yang berbeda berpengaruh sangat nyata $(\mathrm{P}<0,01)$ terhadap kandungan BK, abu, PK, LK, dan SK silase sabut kelapa muda. Terlihat bahwa semakin tinggi penambahan dedak padi, kandungan bahan kering, abu, protein kasar dan lemak kasar silase sabut kelapa muda semakin meningkat. Uji Duncan memperlihatkan bahwa kandungan BK, abu, PK dan LK silase sabut kelapa muda yang tertinggi pada perlakuan P3 yang berbeda $(\mathrm{P}<0,05)$ dengan perlakuan $\mathrm{P} 2$, $\mathrm{P} 1$ dan $\mathrm{P} 0$, dan kandungan $\mathrm{BK}$, abu, PK, dan LK terendah pada perlakuan P0. Sementara kadar SK tertinggi pada perlakuan P2 yang berbeda dengan P0, P1, P3 dan yang terendah pada perlakuan $\mathrm{P} 3$.
Rendahnya kandungan bahan kering pada perlakuan P0 dikarenakan tidak adanya tambahan dedak padi dan rendahnya sumber energi bagi bakteri asam laktat yang melakukan fermentasi. Hal ini sejalan dengan pendapat Barokah et al. (2018) yang menyatakan bahwa tinggi rendahnya kandungan BK silase ditentukan oleh bahan yang digunakan dan aktivitas mikroorganisme selama proses ensilase. Perubahan BK untuk setiap perlakuan dari P0 dengan P1 BK meningkat 2,64\%, P0 dengan P2 BK meningkat 5,28\%, dan P0 dengan P3 BK meningkat hingga 7,07\% dan rata-rata perubahan $\mathrm{BK}$ untuk setiap perlakuan adalah 2,36\%. Kadar bahan kering silase sabut kelapa muda adalah $23,45 \%$ lebih rendah dari penelitian yang dilaporkan oleh Barokah et al. (2018) pada silase pelepah kelapa sawit yang ditambah biomasa indigofera (Indigofera 
zollingeriana) yaitu 42,26\%. Hal ini disebabkan karena jenis bahan baku dan kandungan nutrien bahan baku yang digunakan berbeda.

Meningkatnya kadar abu juga diduga disebabkan selama proses fermentasi, terjadi degradasi bahan organik silase sabut kelapa oleh mikroba selama proses ensilase. Hal ini sejalan dengan pendapat Koten (2010) yang menyatakan bahwa berkurangnya bahan organik terutama isi sel selama proses fermentasi mengakibatkan naiknya kadar abu dan menggunakan nutrien yang ada dalam bahan kering ini sebagai sumber energinya. Perbedaan kadar abu perlakuan P0 dengan P1 adalah 2,80\%, P0 dengan $\mathrm{P} 2$ adalah $3,82 \%$, dan P0 dengan P3 adalah 6,12\%. Kadar abu silase sabut kelapa muda adalah $10,15 \%$ lebih tinggi dari kadar Abu pada penelitian terdahulu tentang silase pelepah kelapa sawit yang ditambah biomasa indigofera (Indigofera zollingeriana) yang dilaporkan Barokah et al. (2018) yaitu 8,36\%.

Perbedaan kadar PK antara perlakuan kontrol (P0) dengan perlakuan penambahan $4 \%$ dedak padi (P1) terjadi peningkatan sebesar $1,16 \%$, perlakuan kontrol (P0) dengan perlakuan penambahan $8 \%$ dedak padi (P2) terjadi peningkatan sebesar $1,72 \%$, dan perlakuan kontrol (P0) dengan perlakuan penambahan $12 \%$ dedak padi (P3) terjadi peningkatan sebesar 2,26\%. Kadar protein silase sabut kelapa yang semakin meningkat karena pada saat proses ensilase, terjadi proses fermentasi yang melibatkan mikroba. Mikroba tersebut kemudian berkembang dalam silase tersebut yang akan meningkatkan kadar PK silase. Ketika dedak ditambahkan mencapai $12 \%$, perkembangan mikroba mengalami peningkatan pertumbuhan yang dibuktikan dengan meningkatnya sumbangan protein mikroba pada silase tersebut. Hal ini sejalan dengan pendapat Kusumaningrum et al. (2012) yang menyatakan bahwa peningkatan kadar protein bahan pakan yang difermentasi akibat adanya aktivitas mikroba dan adanya penambahan protein yang terdapat dalam sel mikroba itu sendiri. Terjadinya peningkatan PK mengindikasikan bahwa penambahan dedak padi dalam silase sabut kelapa muda berdampak baik bagi kadar protein kasar silase sabut kelapa.
Rata-rata kadar protein kasar silase sabut kelapa muda adalah 7,39\% lebih rendah dari yang dilaporkan oleh Barokah et al. (2018) pada silase pelepah kelapa sawit yang ditambah biomasa indigofera (Indigofera zollingeriana) yakni sebesar 8,505\%. Hal ini karena bahan baku dan perlakuan yang digunakan berbeda sehingga asupan protein dari aditif yang ditambahkan juga berbeda.

Perbandingan kandungan LK silase sabut kelapa muda antara perlakuan P0 dengan P1 meningkat sebesar $0,47 \%$, P0 dengan P2 meningkat sebesar $0,94 \%$, dan P0 dengan P3 meningkat sebesar $1,12 \%$. Amrullah et al. (2015) menyatakan bahwa peningkatan kadar lemak kasar pada silase tergantung pada jumlah aditif yang ditambahkan dan kandungan lemak dari bahan aditif tersebut. Rendahnya kandungan lemak kasar pada perlakuan P0 diduga disebabkan oleh tidak adanya tambahan lemak dari dedak, juga adanya degradasi lemak yang ada oleh mikroba yang bekerja selama proses fermentasi. Hal ini sejalan dengan pendapat Hading (2014) yang menyatakan bahwa rendahnya kandungan lemak kasar disebabkan oleh ikatan trigliserida yang dipecah menjadi ikatan yang lebih sederhana antara lain dalam bentuk asam lemak dan alkohol. Kadar lemak kasar silase sabut kelapa muda adalah $1,72 \%$ lebih rendah dari penelitian terdahulu yang dilaporkan oleh Barokah et al. (2018) pada silase pelepah kelapa sawit yang ditambah biomasa indigofera (Indigofera zollingeriana) yaitu $3,06 \%$. Hal ini diduga karena pada penelitian ini, selama proses ensilase terjadi banyak pemecahan lemak dalam bahan pakan menjadi asam lemak.

Perbandingan kandungan serat kasar silase sabut kelapa muda antara perlakuan P0 dengan P1 meningkat sebesar 3,69\%, P0 dengan P2 meningkat sebesar $6,44 \%$, dan P0 dengan P3 terlihat bahwa dengan penambahan dedak sebanyak $12 \%$ terjadi penurunan serat yang signifikan hingga $0,11 \%$ dan ternyata dari penambahan dedak $8 \%$ ke $12 \%$ terjadi penurunan serat sebanyak $6,55 \%$. Terlihat bahwa kadar serat kasar silase makin meningkat dengan bertambahnya dedak hingga $8 \%$ (P2). Hal ini disebabkan adanya penambahan serat dari dedak padi. Ketika dedaknya ditambahkan hingga 12\% kadar serat kasarnya mengalami penurunan. Hal ini disebabkan karena 
terjadinya perubahan serat kasar, yang merupakan dampak dari adanya suasana asam (menurunnya $\mathrm{pH}$ silase hingga 4) yang menyebabkan seratnya mengalami penguraian. Serat yang telah terurai tersebut dimanfaatkan oleh mikroba. Kondisi ini menyebabkan menurunnya kadar serat silase sabut kelapa muda. Hal ini sejalan dengan pendapat Riswandi (2014) yang menyatakan bahwa dalam pengolahan silase dengan tambahan aditif, jumlah ketersediaan sumber energi untukmikroba lebih banyak sehingga populasi dan aktivitas mikroba pendegradasi selulosa serta hemiselulosa meningkat.

Kadar serat kasar silase sabut kelapa muda adalah 24,60\% lebih tinggi dari kandungan SK pada penelitian terdahulu yang dilaporkan Jaelani et al. (2014) tentang pengaruh penyimpanan silase daun kelapa sawit terhadap kadar protein dan serat kasar yaitu 17,50\%. Hal ini karena pada penelitian terdahulu menggunakan jenis aditif yang sama namun lama waktu penyimpanan yang berbeda karena semakin lama penyimpanan proses silase maka kandungan serat kasarnya semakin menurun.

\section{Pengaruh Perlakuan Terhadap Kadar Mineral Silase Sabut Kelapa Muda}

Analisis varians menunjukkan bahwa level penggunaan dedak padi memberikan pengaruh yang sangat nyata $(\mathrm{P}<0,01)$ terhadap kadar $\mathrm{Ca}$, $\mathrm{K}$, dan $\mathrm{P}$ silase sabut kelapa muda.Uji Duncan menunjukkan bahwa kadar $\mathrm{Ca}$ dan $\mathrm{K}$ tertinggi terdapat pada silase sabut kelapa muda tanpa dedak padi $(\mathrm{P} 0)$ yang berbeda $(\mathrm{P}<0,05)$ dengan $\mathrm{P} 1, \mathrm{P} 2$ dan P3. Kadar $\mathrm{Ca}$ dan $\mathrm{K}$ terendah terdapat pada penambahan dedak padi $12 \%$ (P3). Sementara kadar $\mathrm{P}$ tertinggi pada perlakuan $\mathrm{P} 2$ yang berbeda dengan $\mathrm{P} 0, \mathrm{P} 1, \mathrm{P} 3$ dan yang terendah pada perlakuan $\mathrm{P} 0$.

Rata-rata kadar $\mathrm{Ca}$ silase sabut kelapa muda terlihat menurun seiring dengan meningkatnya level dedak padi dalam pengolahan silase sabut kelapa muda. Hal ini disebabkan oleh suasana asam yang terjadi selama penelitian yakni $\mathrm{pH}$ silase sabut kelapa muda pada penelitian ini adalah 4 . Kismiati et al. (2012) menyatakan bahwa mineral $\mathrm{Ca}$ merupakan mineral yang larut dalam asam. Pada situasi asam, terjadi pembengkakkan jaringan, yang menyebabkan mineral $\mathrm{Ca}$ akan mudah terurai dan larut. Hal ini akan mengurangi kadar Ca silase. Kadar Ca silase sabut kelapa muda pada penelitian ini adalah $0,33 \%$ lebih rendah dari penelitian menyatakan bahwa kadar $\mathrm{Ca}$ silase semak bunga putih adalah 2,13\% (Tabun, 2017). Hal ini dapat dimengerti karena perbedaan bahan baku yang digunakan.

Penurunan kadar kalium disebabkan karena selama proses ensilase, mikroorganisme memanfaatkan mineral kalium dari bahan yang ada untuk pertumbuhannya. Suasana asam yang tercipta selama proses ensilase menyebabkan kalium menjadi mudah larut. Kalium yang larut ini akan dimanfaatkan oleh mikroba yang aktif dalam proses ensilase. Kondisi ini menurunkan kadar kalium silase. Kadar kalium pada penelitian ini adalah 1,57\% lebih tinggi dari penelitian Wunu et al. (2016) yang menyatakan bahwa kadar kalium dari biji asam yang diperam dengan nira lontar yaitu $0,52 \%$.

Sine et al. (2018) menjelaskan bahwa mineral terutama fosfor dan kalsium bahan yang terfermentasi mengalami perubahan dan cenderung menurun. Walaupun demikian ketersediaannya bagi ternak menjadi lebih tinggi, karena selama fermentasi terjadi hidrolisis senyawa kompleks menjadi senyawa yang lebih sederhana sehingga lebih mudah tercerna dan terserap oleh ternak.

Rata-rata Kadar fosfor silase sabut kelapa muda semakin meningkat seiring bertambahnya level dedak padi hingga $8 \%$. Kadar ini lebih tinggi dari pada penelitian terdahulu yang menyatakan bahwa kadar fosfor dari silase semak bunga putih (Chromolaena odorata) adalah 0,20 ppm (Tabun, 2017). Irianingrum, (2009) melaporkan bahwa dedak padi yang difermentasi dalam keadaan anaerob dengan $\mathrm{pH} 4,5$, akan mendukung aktifnya enzim fitase sehingga terjadi proses penguraian, dan dapat menurunkan kandungan asam fitat dalam dedak padi. Kandungan fosfor pada dedak padi dalam bentuk asam fitat yaitu $89,9 \%$. Setelah terjadi proses penguraian, mineral fosfor yang terdapat dalam asam fitat akan terlepas dan berperan sebagai sumber fosfor organik. $\mathrm{pH}$ dalam penelitian ini adalah 4, sehingga dengan penambahan dedak padi dalam silase sabut kelapa muda dapat menurunkan kandungan asam fitat dan meningkatkan kadar fosfor hingga 73,61 ppm. Selanjutnya kadar fosfor kembali menurun 
pada P3 yaitu 57,73 ppm, diduga terjadi karena fosfor yang terurai dimanfaatkan oleh mikroba selama proses fermentasi.

\section{KESIMPULAN DAN SARAN}

Berdasarkan hasil dan pembahasan, maka dapat disimpulkan bahwa :

1. Penambahan dedak padi hingga level $12 \%$ meningkatkan kadar BK, Abu, PK, LK, dan menurunkan kadar $\mathrm{Ca}$ dan $\mathrm{K}$ pada silase sabut kelapa muda.

2. Penambahan dedak hingga $8 \%$, meningkatkan kadar serat kasar dan fosfor silase sabut kelapa muda, tetapi jika dinaikkan levelnya menjadi $12 \%$ justru menurunkan serat kasar dan fosfor.

Dari kesimpulan di atas disarankan bahwa:

1. Pada kondisi yang sama, pembuatan silase sabut kelapa muda dengan kualitas nutrien terbaik, perlu ditambahkan dedak padi sebanyak $12 \%$ dari berat bahan.

2. Perlu dilakukan penelitian lebih lanjut dengan perlakuan yang berbeda dan bahan aditif yang berbeda.

\section{DAFTAR PUSTAKA}

Adeyi O. 2010. Proximate Composition Of Some Agricultural Wastes In Nigeria And Their Potential Use In Activated Carbon Production. J. Appl. Sci. Environ. Manage 14(1): 55-58, Www.Bioline.Org.Br/Ja

Amrullah F. Liman L. dan Erwanto E. 2015. Pengaruh Penambahan Berbagai Jenis Sumber Karbohidrat Pada Silase Limbah Sayuran Terhadap Kadar Lemak Kasar, Serat Kasar, Protein Kasar Dan Bahan Ekstrak Tanpa Nitrogen. Jurnal Ilmiah Peternakan Terpadu 3(4): 221-227, Https://Doi.Org/10.23960/Jipt.V3i4.1102.

Anas M. R. dan Syahrir D. 2017. Pengaruh Penggunaan Jenis Aditif Sebagai Sumber Karbohidrat Terhadap Komposisi Kimia Silase Rumput Mulato. J. Agrisains 18(1): 13-22,

Http://Jurnal.Untad.Ac.Id/Jurnal/Index.Ph p/Agrisains/Article/View/9929

Barokah Y. Ali A. dan Erwan E. 2018. Nutrisi Silase Pelepah Kelapa Sawit Yang Ditambah Biomassa Indigofera (Indigofera Zollingeriana). Jurnal Ilmiah Ilmu-Ilmu Peternakan 20(2): 59-68,
Https://Doi.Org/10.22437/Jiiip.V20i2.477 2.

Basri B. Nurhaedah N. dan Fitriani F. 2019. Kandungan Kalsium (C) Dan Fospor (P) Silase Kombinasi Jerami Padi Dan Daun Lamtoro Sebagai Pakan Ternak Ruminansia. Bionature 20(1): 21-26, Https://Doi.Org/10.35580/Bionature.V20i 1.9756 .

Chrysostomus H. Y. Koni T. N. I. And Foenay T. A. Y. 2020. Pengaruh Berbagai Aditif Terhadap Kandungan Serat Kasar Dan Mineral Silase Kulit Pisang Kepok. Jurnal Ilmu Peternakan Dan Veteriner Tropis (Journal Of Tropical Animal And Veterinary Science) 10(2): 91-97, Https://Doi.Org/10.46549/Jipvet.V10i2.10 0

Gomez K. A. dan Gomez A. A. 2010. Prosedur Statistik Untuk Penelitian Pertanian. Jakarta: Universitas Indonesia.

Hading A. R. 2014. Kandungan Protein Kasar, Lemak Kasar, Serat Kasar Dan Betn Silase Pakan Lengkap Berbahan Dasar Rumput Gajah Dan Biomasa Murbei. Universitas Hasanuddin, Makassar.

Irianingrum R. 2009. Kandungan Asam Fitat Dan Kualitas Dedak Padi Yang Disimpan Dalam Keadaan Anaerob. Ipb (Bogor Agricultural University), Bogor.

Jaelani A. Gunawan A. dan Asriani I. 2014. Pengaruh Lama Penyimpanan Silase Daun Kelapa Sawit Terhadap Kadar Protein Dan Serat Kasar. Ziraa'ah Majalah Ilmiah Pertanian 39(1): 8-16, Https://Doi.Org/10.31602/Zmip.V39i1.29.

Kismiati S. Yuwanta T. Zuprizal And Supadmo. 2012. The Performance Of Laying Hens Fed Different Calcium Source. Journal of The Indonesian Tropical Animal Agriculture 37(4): 263270, Https://Doi.Org/10.14710/Jitaa.37.4.263270.

Koten B. B. 2010. Kandungan Nutrien Silase Buah Semu Jambu Mete Sebagai Pakan Pada Berbagai Level Tepung Gaplek Dan Lama Pemeraman. Partner. Buletin Pertanian Terapan 17(2): 120-126, Https://Doi.Org/10.35726/Jp.V17i2.52

Kusumaningrum M. Sutrisno C. dan Prasetiyono P. 2012. Kualitas Kimia 
Ransum Sapi Potong Berbasis Limbah Pertanian Dan Hasil Samping Pertanian Yang Difermentasi Dengan Aspergillus Niger. Animal Agriculture Journal 66(2): 37-39.

Munira S. Ode Nafiu L. dan Tasse A. M. 2016. Performans Ayam Kampung Super Pada Pakan Yang Disubttusi Dedak Padi Fermentasi Dengan Fermentor Berbeda. Jurnal Ilmu Dan Teknologi Peternakan Tropis 3(2): 21-29, Https://Doi.Org/10.33772/Jitro.V3i2.1683

Riswandi. 2014. Kualitas Silase Eceng Gondok (Eichhornia Crassipes) Dengan Penambahan Dedak Halus Dan Ubi Kayu Riswandi. Jurnal Peternakan Sriwijaya 3(1): $\quad 1-6$, Https://Doi.Org/Https://Doi.Org/10.33230 /Jps.3.1.2014.1726
Sine Y. Endang D. dan Soetarto S. 2018. Perubahan Kadar Vitamin Dan Mineral Pada Fermentasi Tempe Gude (Cajanus Cajan L.). Jurnal Saintek Lahan Kering 1(1): $1-3$, Https://Doi.Org/Https://Doi.Org/10.32938 /Slk.V1i1.414.

Tabun M. 2017. Kandungan Mineral Silase Bunga Putih (Chromolaena Odorata) Akibat Penambahan Level Tepung Gaplek Yang Berbeda. Kupang.

Wunu M. G. Jermias J. A. Koten B. B. Wea R. dan Ndolu D. A. J. 2016. Perubahan Kadar Kalsium, Fosfor, Dan Kalium Biji Asam Yang Diperam Dengan Nira Lontar Pada Level Yang Berbeda. Jurnal Ilmu Ternak Universitas Padjadjaran 16(2): 10-15, Https://Doi.Org/Https://Doi.Org/10.24198 /Jit.V16i2.11570 